\title{
Primary Cerebellopontine Angle Rathke's Cleft Cyst: Case Report
}

\section{Primer Serebellopontin Açı Rathke Yarı̆̆ Kisti: Olgu Sunumu}

\author{
Jie ZHOU ${ }^{1}$, Ligang $\mathrm{CHEN}^{1}$, Chao $\mathrm{ZHANG}^{2}$, Hui OUYANG ${ }^{3}$, Chotai SILKY ${ }^{3}$, Songtao $\mathrm{QI}^{3}$ \\ ${ }^{1}$ The Affiliated Hospital of Luzhou Medical College, Department of Neurosurgery, Lu Zhou, PR China \\ ${ }^{2}$ Sun Yat-sen University Cancer Cencer, Department of Pathology, Guangzhou, PR China \\ ${ }^{3}$ Southern Medical University, Nanfang Hospital, Department of Neurosurgery, Guang Zhou, PR China
}

Corresponding Author: Songtao QI / E-mail: zj000718@yeah.net

\begin{abstract}
We report a case of 25-year-old man presenting with a 2-year history of decreased hearing and tinnitus on the right side. Neurological examination revealed profound right retrocochlear sensorineural hearing abnormality, mild right facial spasm and positive Romberg sign. Magnetic resonance imaging (MRI) revealed a giant lesion, hypointense on T1-weighted image and hyperintense on T2-weighted image at the right cerebellopontine angle (CPA). The patient underwent a right suboccipital retrosigmoid craniotomy. Histologically, the cyst depicted characteristics of RCC and was lined by columnar epithelium or stratified squamous epithelium without keratinization. There was gradual improvement of his hearing and neurological deficits 5 months after surgery. There was no recurrence at 60 months follow-up. This case underscores the importance of considering RCC in the differential diagnosis of CPA lesions. The selection of operative approach, based on the relation of cyst wall to normal brain tissue is optimal strategy.
\end{abstract}

KEYWORDS: Rathke's cleft cyst, Cerebellopontine angle, Therapy

öz

2 yıllık sağ tarafta azalmış işitme ve tinnitus hikayesi ile gelen 25 yaşında bir erkek olguyu sunuyoruz. Nörolojik muayene belirgin sağ retrokohlear sensörinöral işitme bozukluğu, hafif sağ fasiyal spazm ve pozitif Romberg bulgusu gösterdi. Manyetik rezonans görüntüleme (MRG), sağ serebellopontin açı (SPA), T1 ağırlıklı görüntüde hipointens ve T2 ağırlıklı görüntüde hiperintens olan dev bir lezyon gösterdi. Hastaya sağ suboksipital retrosigmoid kraniyotomi yapıldı. Histolojik olarak kist Rathke yarığı kisti özellikleri gösteriyordu ve keratinizasyon olmadan çok katlı skuamöz epitel veya kolumnar epitelle örtülüydü. Cerrahiden 5 ay sonra işitmede ve nörolojik defisitte giderek düzelme oldu. 60 aylık takipte nüks görülmedi. Bu olgu SPA lezyonlarının ayırıcı tanısında Rathke yarı̆̆ı kisti düşünülmesinin önemini vurgulamaktadır. Kist duvarının normal beyin dokusuna ilişkisi temelinde operatif yaklaşımın seçilmesi optimum stratejidir.

ANAHTAR SÖZCÜKLER: Rathke yarığı kisti, Serebellopontin açı, Tedavi

\section{INTRODUCTION}

Rathke's cleft cyst (RCC), derived from remnants of Rathke's pouch is an uncommon lesion located in the sella turcica. RCCs had been reported to extend from the suprasellar region to posterior fossa. We report a rare case of de novo RCC of cerebellopontin angle (CPA) region compressing the cranial nerve VIII and presenting with decreased hearing and tinnitus.

\section{CASE REPORT}

A 25-year-old man presented with a 2-year history of progressive hearing loss and tinnitus on the right side. During last six months the symptoms worsened and were associated with intermittent dizziness, headaches, nausea, vomiting and right facial numbness. Neurological examination revealed a profound right retrocochlear sensorineural hearing loss, mild right facial spasm and positive Romberg sign. Computer tomography (CT) scan showed a rounded sharp mass with a hypointensity at the right cerebellopontine angle. Magnetic resonance imaging $(\mathrm{MRI})$ revealed a well-defined lesion of $40 \mathrm{~mm} \times 30 \mathrm{~mm} \times 46 \mathrm{~mm}$ dimensions that was hypointense on T1-weighted image and hyperintense on T2-weighted image. The lesion did not show apparent enhancement on gadolinium enhanced T1-weighted image (Figure 1A-E). A right suboccipital retrosigmoidal craniotomy was performed for cyst content evacuation and resection of the membrane. A gray cystic mass was exposed at the cerebellopontine angle following sufficient release of cerebrospinal fluid from the cisterna magna. Cranial nerve VII was located at internal, superior and anterior to the cyst. The cyst was compressing the cranial nerve VIII between the arachnoid membrane and the cyst envelope. There were mild adhesions between cyst and surrounding tissue. The cyst wall was separated by sharp microdissection of adhesions. The gray turbid cyst fluid was removed using suction and total resection of the cyst membrane was achieved.

Histopathological examination revealed that the cyst was lined by ciliated columnar epithelium, cuboidal epithelium and 
stratified squamous epithelium without keratinization; which was consistent with RCC (Figure 2A,B). The postoperative course was uneventful. There was a gradual improvement in hearing and neurological deficits 5 month postoperatively. The patient was asymptomatic at 60 months follow-up.

\section{DISCUSSION}

\section{Incidence And Origin}

RCC is an uncommon, benign, non-neoplastic cystic lesion, which originates from remnants of Rathke's pouch. Despite a high incidence of RCCs being described in the autopsy series as $13-22 \%$, symptomatic RCCs are deemed to be a rare lesions.
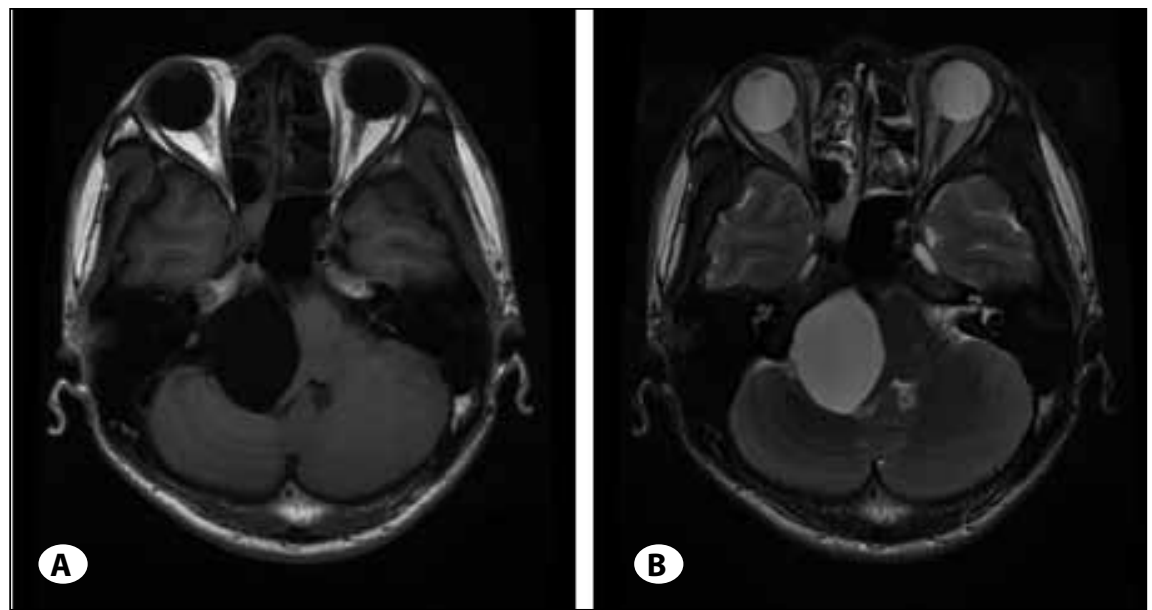

Figure 1: A) Preoperative Axial T1-

weighted MRI showing a hetergeneous,

hypointense lesion in the right

cerebellopontine angle with a well-

defined boundary; B) Preoperative

Axial T2-weighted MRI showing a

homogeneous hyperintense lesion

in the right cerebellopontine angle;

C) Preoperative sagittal, D) coronal and E) Axial, T1-weighted MRIs with gadolinium enhancement showing a nonenhancing, cystic lesion filling the right cerebellopontine angle with distortion of the fourth ventricle.
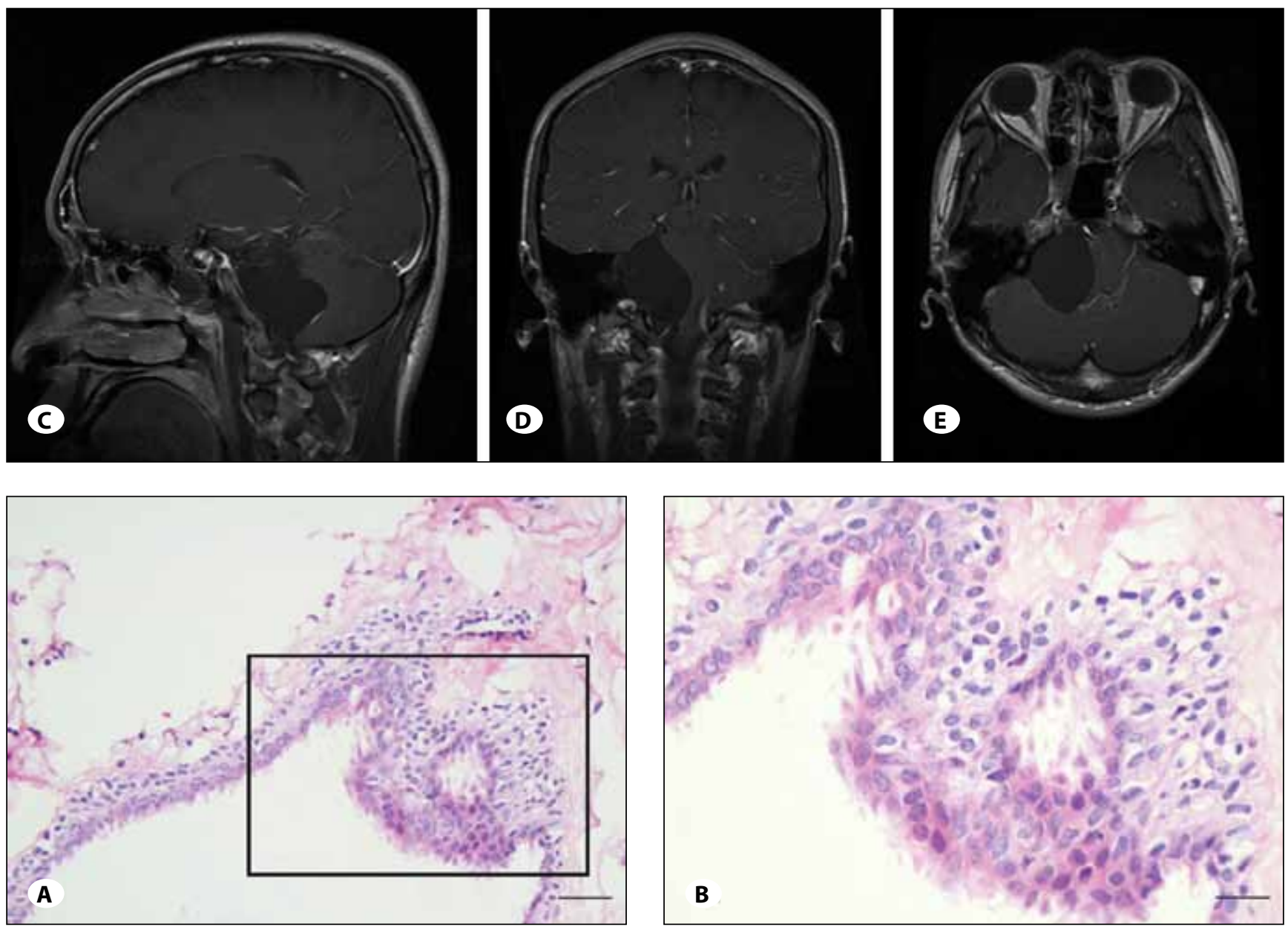

Figure 2: Rathke's cleft cyst showing cyst lined by ciliated columnar epithelium, cuboidal epithelium and stratified squamous epithelium without keratinization; A) Hematoxylin and eosin (H\&E) $\times 200$, B) H\&E $\times 400$. 
RCCs are typically located in an intrasellar or combined intraand suprasellar intrasellar regions between the pars anterior and the pars intermedia of the pituitary gland. Several reports of lesions located entirely suprasellar or those extending from the sellar region to anterior or posterior fossa have been reported (3). We report a rare case of isolated RCC located at CPA region.

Ectopic locations of primary RCC include the nasopharynx, the sphenoid sinus, prepontine cistern and the posterior fossa. The de novo evolution of RCC in CPA is rarity. It has been suggested that RCCs arise from embryonic squamous cells of the involuted craniopharyngeal duct, which initially connects Rathke's pouch with stomodeum. During the process of proliferation and migration of the cells of Rathke's pouch leading to the formation of adenohypophysis, cell remnants of the craniopharyngeal duct can spread through the intrasellar and suprasellar region which is the most frequent location of RCCs. However, few cells might theoretically move to CPA. Failure of ectopic cell remnants in CPA to regress and increasing of the cystic secretion can result in the formation of symptomatic RCCs.

\section{DIFFERENTIAL DIAGNOSIS}

\section{Cystic Acoustic Neuroma}

Acoustic neuroma is one of the most common intracranial tumors, comprising $8-10 \%$ of all primary intracranial tumors and $80 \%$ of cerebellopontine angle tumors. Cystic neuroma is less frequent and accounts for $9.7-24 \%$ of all acoustic neuromas. The clinical and radiological features of these lesions are similar to other cystic lesions of CPA. RCCs of CPA can be easily misdiagnosed preoperatively because their CT appearances and clinical manifestations resemble cystic acoustic neuroma. However, cystic acoustic neuromas are associated with erosion of the internal auditory canal as they arise from cranial nerve VIII and usually demonstrate an enhancing tumor component on a T1-weighted gadoliniumenhanced MRI. Diagnosis of RCCs should be considered in case of a large cystic CPA lesion.

\section{Epidermoid Cyst}

Intracranial epidermoid cyst accounts for $0.2-1.8 \%$ of all brain tumors. Epidermoid cysts are most commonly located at the CPA, which constitutes $40-61 \%$ of intracranial epidermoid cysts. RCCs of CPA can be misdiagnosed preoperatively as they share imaging features and clinical manifestations with epidermoid cysts at CPA. RCCs demonstrate expansive growth to squeeze the peripheral structures. However, epidermoid cysts usually insinuate themselves in to cisterns adjacent to the skull base to exhibit an imaging appearance of conformal growth pattern as the growth of the epidermoid cyst is limited by the surrounding arachnoid membrane.

\section{Surgical Treatment}

Symptomatic RCCs require surgical resection; however, it is controversial whether the radical resection of cysts wall is feasible. Chuang et al concluded that aggressive resection is associated with good surgical results and low recurrence. Simple opening of the cyst might lead to recurrence, as healing of the cyst wall results in re-accumulation of cystic contents from cyst epithelium that contains secretory cells (1). Higgins et al has stated that wild-resection of the cyst wall does not appear to reduce the overall rate of recurrence, and more aggressive resections were associated with more complications in their series (2). It has been reported that adhesion of the cyst wall to the normal structure is the major concern when deciding on the operative strategies during the operation. However, in the absence of such adhesion, in intact suprasellar cysts, radical excision might be feasible. In the present case, despite adherence of the cyst wall to surrounding structures, the drainage of cyst content as well as complete excision of cyst wall was achieved with protection of the compressed cranial nerves. A suboccipital retrosigmoidal approach provided optimal exposure for cyst resection in CPA region. The neurologic deficits recovered gradually over 5 months postoperative and no recurrence was noted.

\section{REFERENCES}

1. Chuang CC, Chen $Y L$, Jung SM, Pai PC: A giant retroclival Rathke's cleft cyst. J Clin Neurosci 17:1189-1191, 2010

2. Higgins DM, Van Gompel JJ, Nippoldt TB, Meyer FB: Symptomatic Rathke cleft cysts: Extent of resection and surgical complications. Neurosurg Focus 31:2, 2011

3. Zhou L, Luo L, Hui X, Chen H, Yu B, Guo G, You C: Primary Rathke's cleft cyst in the cerebellopontine angle associated with apoplexy. Childs Nerv Syst 26:1813-1817, 2010 